\title{
PEMBERDAYAAN KAUM PEREMPUAN DALAM MENUNJANG PENINGKATAN PENDAPATAN KELUARGA PERSPEKTIF HUKUM EKONOMI SYARI'AH
}

\author{
Burhanuddin \\ Institut Agama Islam Hamzanwadi NW Lombok Timur \\ Email: burhanu1975@gmail.com
}

\begin{abstract}
Abstrak: Penelitian ini bertujuan untuk mengetahui bagaimana Pemberdayaan Kaum Perempuan Dalam Menunjang Peningkatan Pendapatan Keluarga Perspektif Hukum Ekonomi Syari'ah. Adapun pendekatan penelitian yang digunakan dalam penelitian ini adalah penelitian lapangan (field research) dan penelitian kepustakaan (library research). Berdasarkan hasil pengambilan data perempuan yang ikut berperan meningkatkan pendapatan keluarga pada wanita pengrajin Ampet di Desa Saba Kecamatan Janapria membawa implikasi yang positif terhadap sosial ekonomi keluarganya dan sudah sesuai dengan ketentuan-ketentuan islam, dimana perempuan lebih memperioritaskan kebutuhan primer, dibandingkan sekunder dan tersiernya sebab perekonomian rumah tangga muslim memegang prinsip mengutamakan kebutuhan primer dalam membelanjakan hartanya, setelah itu barulah kebutuhan sekunder dan tersiernya. Sikap pertengahan dan seimbang, yang dilakukan oleh perempuan dalam perekonomian rumah tangga terdiri atas dasar sikap pertengahan dalam segala perkara, seperti pertengahan dalam pengaturan harta dengan tidak berlebihan dan tidak terlalu hemat sehingga terkesan kikir, dan mampu mengalokasikan sisa saldo untuk kepentingan zakat, infak dan sedekah.

Kata kunci: pemberdayaan perempuan, peningkatan pendapatan
\end{abstract}

Abstract: This study aims to determine how the empowerment of women in increasing family income from the perspective of Islamic economic law. The research approach used in this research is field research and library research. Based on the results of observations of women who plays a role in increasing family income for women Ampet craftsmen in Saba Village, Janapria District, it has positive implications for their family's socio-economy and is in accordance with Islamic provisions, where women prioritize primary needs, compared to secondary and tertiary needs because of the home economy. The Muslim ladder holds the principle of prioritizing primary needs in spending their assets, then only secondary and tertiary needs. The middle and balanced attitude which is carried out by women in the household economy consists of the basic attitude in all cases, such as middle in the management of assets that is not excessive and not too frugal so that it seems stingy, and is able to allocate the remaining balance for the benefit of zakat, infaq and sadaqoh

Key words: empowering women, increasing income 


\section{PENDAHULUAN}

Menurut Riant Nugroho menyatakan tujuan dari program permberdayaan perempuan, antara lain: 1). Meningkatkan kemampuan kaum perempuan untuk melibatkan diri dalam program pembangunan, sebagai partisipasi aktif (subjek) agar tidak sekedar menjadi objek pembagunan seperti yang terjadi selama ini. 2). Meningkatkan kemampuan kaum perempuan dalam kepemimpinan, untuk meningkatkan posisi tawar-menawar dan keterlibatan dalam setiap pembangunan baik sebagai perencana, pelaksana, maupun melakukan monitoring dan evaluasi kegiatan. 3). Meningkatkan kemampuan kaum perempuan dalam mengelola usaha skala rumah tangga, industri kecil maupun industri besar untuk menunjang peningkatan kebutuhan rumah tangga, maupun untuk membuka peluang kerja produktif dan mandiri. 4). Meningkatkan peran dan fungsi organisasi perempuan di tingkat lokal sebagai wadah pemberdayaan kaum perempuan agar dapat terlibat secara aktif dalam program pembangunan pada wilayah tempat tinggalnya (Nugroho, 2008: 163-164).

Fakta yang ada belum menunjukkan keberhasilan pemerintah dalam memperdayakan kaum wanita dalam menunjang ekonomi keluarga. Hal ini terlihat berdasarkan data Badan Pusat Statistik (BPS) yang telah diolah kembali, tingkat partisipasi angkatan kerja perempuan di Indonesia 51,7\% dan tingkat partisipasi angkatan kerja laki-laki mencapai $88,5 \%$. Data tersebut menunjukkan tingkat partisipasi kerja perempuan di Indonesia masih rendah dibanding tingkat partisipasi kerja lakilaki (Boediono,1993:5).

Dalam Persfektif Hukum Ekonomi Syari'ah, sistem perekonomian mengandung aturan-aturan Syara' yang dapat mengatur kehidupan perekonomian suatu rumah tangga, masyarakat, dan umat Islam secara keseluruhan. Suatu keharusan bagi seorang muslim untuk mengetahui prisip-prinsip dasar Ekonomi dalam Perspektif Islam agar dia tetap menempuh jalan lurus yang didasarkan pada hidayah Allah. Ketentuan perekonomian Islam mencakup peraturan tentang pendapatan, pengeluaran (pembelanjaan), penyimpanan, penabungan dan pemilikan. Ketentuan-ketentuan itu mengatur Perekonomian rumah tangga muslim agar dapat mewujudkan tujuan-tujuan umum hukum Islam, yaitu memelihara akal, agama, keturunan, kehormatan, dan harta disamping agar dapat mewujudkan pemenuhan kebutuhan spiritual dan pemenuhan kebutuhan material.

Islam telah menjamin hak perempuan untuk bekerja sesuai dengan tabiatnya dan aturan-aturan syariat dengan tujuan untuk menjaga kepribadian dan kehormatan perempuan. Meskipun demikian, Istri harus memiliki keyakinan bahwa yang utama dalam hidupnya adalah mengatur urusan rumah 
tangga. Di dalam surat an-Nisaa':32 dapat ditafsirkan sebagai berikut:

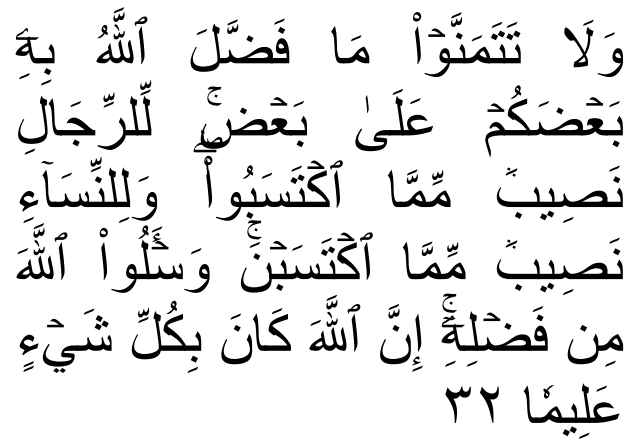

Artinya: "Dan janganlah kamu iri hati terhadap apa yang dikaruniakan Allah kepada sebahagian kamu lebih banyak dari sebahagian yang lain. (Karena) bagi orang laki-laki ada bahagian dari pada apa yang mereka usahakan, dan bagi para wanita (pun) ada bahagian dari apa yang mereka usahakan, dan mohonlah kepada Allah sebagian dari karunia-Nya. Sesungguhnya Allah Maha Mengetahui segala sesuatu" (Q.S An Nisa'. 32)

Para mufassirin berkesimpulan bahwa di dalam ayat tersebut terbukti atas hak perempuan untuk bekerja. Dalam sejarah perjalanan Rasulullah telah membuktikan adanya partisipasi kaum perempuan dalam peperangan, dengan tugas mengurusi masalah pengobatan, menyediakan alat-alat, dan mengangkut prajurit yang terluka. Selain itu, telah terbukti bahwa terdapat sebagian perempuan yang menyebutkan diri dalam peniagaan dan membantu suami dalam pertanian. Pekerjaan yang dibolehkan bagi perempuan adalah pekerjaan yang berhubungan dengan kerumah tanggaan, yaitu yang dapat memenuhi hak-hak suami dan anak-anaknya. Dia harus berpegang kepada aturan-aturan syara' yang mengaturnya (Syahatah, 1998: 64).

Dari hasil observasi awal, kerajinan ampet di Desa Saba berdiri sejak tahun 90-an dan eksis sampai sekarang, dengan jumlah pekerja sebanyak 50-an orang ibu-ibu rumah tangga di Desa Saba. Kerajinan ampet ini didirikan atas inisiatif dari salah satu ibu rumah tangga bernama ibu Sri Wahyuni, sebagai upaya memberdayakan ibu-ibu rumah tangga yang tidak memiliki penghasilan atau menganggur. Ibu Sri Wahyuni memberikan fasilitas tempat, alat dan melatih pembuatan kerajinan ampet. Dengan adanya kerajinan ampet ini, ibu-ibu yang awalnya hanya mengurus rumah tangga dan berbincangbincang sesuatu yang tidak bermanfaat, sekarang mendapatkan manfaat ilmu dan yang lebih menguntungkan lagi memiliki penghasilan sehingga membantu perekonomian keluarga (Wawancara dengan ibu Sri Wahyuni pada tanggal 02 juli 2019).

Upah yang diperoleh ibu-ibu dari bekerja sebagai pengrajin ampet rata-rata untuk satu bulannya berkisar antara Rp. 400.000,-Rp. 500.000,-. Dengan penghasilan yang tidak terlalu banyak, tapi setidaknya dapat membantu ekonomi keluarga. Uang upah tersebut, biasanya ada yang ditabung, ada juga yang dipakai untuk uang jajan anak-anaknya dan 
kebutuhan pribadi para ibu-ibu tanpa harus meminta dari suami. Pendapatan yang tidak sebanding dengan pendapatan karyawan kantor tidak menjadikan ibu-ibu di Desa Saba merasa iri dan malas. Karena mereka sadar, kerajinan ini, hanya kerja sampingan. Pengrajin di sini tidak dituntut harus berangkat terus setiap harinya. Mereka tetap bisa bekerja membuat kerajinan ampet di rumah masing-masing. Dengan begitu mereka tetap mendapatkan penghasilan walaupun tidak berangkat (Wawancara Dengan Beberapa Ibu-Ibu Pengrajin Ampet Pada Tanggal 03 Juli 2019).

\section{METODOLOGI PENELITIAN}

Jenis Penelitian

Adapun pendekatan penelitian yang digunakan dalam penelitian ini adalah penelitian lapangan (field research) dan penelitian kepustakaan (libraryresearch). Penelitian ini merupakan penelitian deskriptif kuantitatif dimana hasil pengujian nantinya akan dianalisis serta dipaparkan dan bertujuan untuk memperoleh gambaran lengkap mengenai tingkat partisipasi perempuan dalam meningkatkan perekonomian keluarga menurut perspektif Hukum Ekonomi Syari'ah di Desa Saba.

\section{Populasi dan Sample}

Populasi dalam penelitian ini adalah kaum perempuan pengrajin ampet di Desa Saba Kecamatan Janapria Kabupaten Lombok
Tengah yang berjumlah -+ 50 responden yang diambil dari perempuan pengrajin ampet, karena dalam penelitian ini jumlah populasinya tidak satu kampong maka sebagian dari responden tersebut dijadikan sampel.

\section{Metode dan Teknik Pengumpulan Data}

Untuk mendapatkan data-data tersebut maka peneliti akan menggunakan instrument sebagai berikut:

a. Observasi yaitu peneliti melakukan pengamatan langsung di lapangan untuk mendapatkan gambaran secara nyata baik terhadap subjek maupun objek penelitian.

b. Wawancara yaitu melakukan tanya jawab dengan mengajukan beberapa pertanyaan secara langsung kepada responden yang berhubungan dengan penelitian ini. Alat yang digunakan dalam penelitian ini meliputi camera, kuesioner, dan alat tulis.

\section{Analisis Data}

Dalam penelitian ini peneliti menggunakan Metode analisa data yang bersifat deskriptif Kualitatif, dimana setelah data terkumpul kemudian dilakukan penganalisaan secara kualitatif lalu di gambarkan dalam bentuk uraian.

\section{PEMBAHASAN}

Berdasarkan hasil penelitian peneliti pada perempuan di Desa Saba Kecamatan Janapria Kabupaten Lombok Tengah sebagai berikut: 


\section{Peran Ekonomi Perempuan.}

Terdapat beberapa ibu rumah tangga yang telah terbiasa ikut mencari nafkah guna membantu suami dalam meningkatkan taraf ekonomi. Dari beberapa perempuan atau ibu rumah tangga yang dimaksud yaitu sebagai pengerajin Ampet. Keikutsertaan perempuan sebagai seorang istri dalam mencari nafkah bersama suami meskipun dengan profesi berbeda, tentu akan membantu meningkatkan pendapatan keluarga. Jika pendapatan suami dan juga istri digabungkan akan bertambah bahkan akan berlipat, dibandingkan dengan seorang suami yang bekerja seorang diri dalam mencari nafkah untuk keluarga. Mengacu pada asumsi pendapatan yang dinyatakan oleh Keynes bahwa semakin tinggi pendapatan maka akan semakin tinggi pengeluaran, pernyataan ini yang menjadi acuan responden dalam menanggapi keadaan perekonomian rumah tangganya, karena kebutuhan yang ada tidak sesuai dengan apa yang didapat di hari itu pula.

\section{Tujuan Perempuan Bekerja.}

Pengrajin Ampet yang dilakukan oleh ibu-ibu rumah tangga yang ada di Desa Saba rata-rata bekerja dengan tujuan untuk dapat membantu suami, disamping itu juga dapat membantu meningkatkan perekonomian rumah tangganya karena sebagian besar perekonmian yang tidak mencukupi. Tujuan perempuan bekerja adalah tidak lain adanya harapan peningkatan perekonomian keluarga serta memperoleh kebahagiaan, asumsi menyatakan bahwa salah satu kebahagiaan seseorang terletak pada kecukupan ekonomi keluarga. Sebagaimana yang tertulis dalam Hadist Nabi Saw:

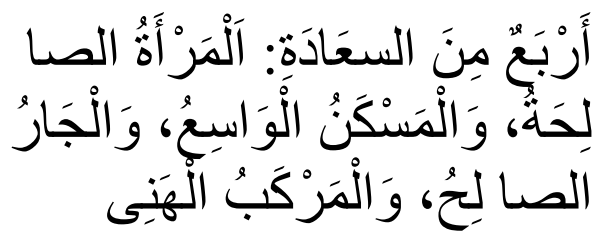

Artinya: "Ada empat perkara termasuk kebahagiaan :istri yang shalihah, tempat tinggal yang lapang, teman atau tetangga yang baik dan kendaraan yang nyaman"

Selain untuk membantu suami, untuk diri sendiri dan keluarga ada juga dari sebagian wanita pengrajin Ampet yang beralasan kerja untuk sampingan. Seperti halnya yang diungkapkan oleh ibu Marhamah salah satu pengrajin Ampet. (Wawancara dengan ibu Marhamah pengrajin Ampet pada tanggal 31 Agustus 2019).

\section{Izin Suami Terhadap Istri Yang Bekerja.}

Perempuan di Desa Saba dalam menjalankan kerajinan ampet, pada dasarnya telah mendapat dukungan (izin) dari suami mereka, hal ini dilakukan karena untuk dapat memenuhi kebutuhan sehari-hari. (Wawancara dengan Ibu Yum pengrajin Ampet pada tanggal 31 Agustus 2019). 
Perempuan Yang Telah Melaksanakan Kewajiban Sebagai Ibu Rumah Tangga.

Menurut observasi peneliti kebanyakan dari perempuan pengrajin Ampet di Desa Saba Kecamatan Janapria telah melaksanakan kewajibannya sebagai ibu rumah tangga dan sebagai istri dari suaminya. Tapi ada juga sebagian dari wanita pengrajin Ampet ini yang kadang-kadang lalai terhadap kewajibannya sebagai ibu rumah tangga karna terlanjur menikmati pekerjaannya. Sedangkan wanita pengrajin Ampet yang belum melaksanakan kewajibannya sama sekali sebagai ibu rumah tangga itu tidak ada.

\section{Waktu Luang Yang Disediakan Perempuan}

\section{Untuk Keluarga.}

Dalam kesibukan sehari-hari wanita pengerajin Ampet yang berada di Desa Saba Kecamatan Janapria masih bisa menyisihkan waktu untuk keluarga mereka. Dari hasil wawancara yang peneliti lakukan tidak ada suami yang tidak mendukung istrinya untuk bekerja sebagai pengrajin ampet.

\section{Lama Perempuan Melakukan Pekerjaan.}

Pekerjaan atau pengrajin yang ditekuni oleh para perempuan yang berpartisipasi dalam pengrajin Ampet adalah dari puluhan tahun yang lalu tetapi karena kerajinan Ampet ini memiliki masa-masa tertentu itulah sebabnya ada kalanya pengrajin berhenti untuk melakukannya tetapi untuk sekarang ini kerajinan ini lagi buming-bumingnya sehingga pengrajinpun jadi bertambah.(Wawancara dengan ibu Sam pengrajin Ampet pada tanggal 04 September 2019). Tetapi ada juga ibu rumah tangga yang baru saja ikut berkecimpung dalam pekerjaan ini.(Wawancara dengan ibu Rifki pengrajin Ampet pada tanggal 04 Sepetember 2019). Ketujuh, Tingkat Pendapatan Perempuan Perbulan.

Penghasilan kaum perempuan yang berpartisipasi dalam meningkatkan perekonomian keluarga sebagai pengrajin Ampet dapat menghasilkan setiap bulan yaitu Rp.750.000 - 1.000.000, ada juga responden yang berpenghasilan Rp.400.000 - 750.000 per bulan dan ada juga yang berpenghasilan Rp.400.000 - 500.000 per bulan. Dapat dilihat bahwa penghasilan dalam 1 bulan kaum perempuan yang berpartisipasi dalam meningkatkan pendapatan keluarga sebagai pengrajin Ampet di Desa Saba Kecamatan Janapria bisa membantu meningkatkan perekonomian keluarga dan sebagian dari kaum perempuan pengrajin Ampet ini mengatakan cukup dalam memenuhi kebutuhan keluarga. Dan sebagian mengatakan tidak mencapai Rp.750.000 - 1.000 .000 per bulan, kadangkadang tidak stabil atau menurun tergantung banyaknya penghasilan Ampet yang dihasilkan dalam 1 minggu. Dimana dalam penjualan Ampet per satu buah diambil dengan harga Rp.25.000 jadi semakin banyak Ampet yang didapatkan per minggu semakin banyak 
pendapatan yang didapat oleh pengrajin ampet tersebut.

\section{Penghasilan Perempuan dalam Mening- katkan Perekonomian Keluarga.}

Pengrajin yang dijalankan oleh para perempuan atau ibu-ibu untuk membantu meningkatkan perekonomian keluarga adalah cukup berhasil dalam membantu meningkatkan perekonomian keluarga, karena sebagian dari mereka mengatakan sanggup atau mampu untuk membiayai sekolah anaknya. Walaupun masih ada sebagian responden yang menyatakan cukup untuk kebutuhan sehari-hari. Kesembilan, Tanggapan Perempuan Menyukai Pekerjaan Kerajinan Ampet. Para perempuan yang berpartisipasi (bekerja) sebagai pengrajin Ampet di Desa Saba Kecamatan janapria Kabupaten Lombok Tengah. Kebanyakan kaum perempuan menyukai pekerjaan yang mereka tekuni dan ada juga mereka tidak suka dengan pekerjaan ini, karena keadaan yang tidak berkecukupan, mereka membuat Ampet untuk bisa membantu suami di Desa Saba mayoritas pencarian suami sebagai petani dengan penghasilan yang tidak tetap yang dipengaruhi oleh beerapa kendala seperti pengaruh musim dan cuaca sehingga pendapatan suami tidak cukup memenuhi kebutuhan keluarga.

Latar belakang perempuan ikut berperan dalam melakukan aktivitas mencari nafkah itu disebabkan oleh adanya beberapa faktor, ada karena faktor ekonomi keluarga yang dirasa kurang mencukupi untuk memenuhi kebutuhan keluarga sehingga harus ditopang oleh kedua belah pihak (suami,istri), faktor dimana seorang perempuan yang harus menjadi tulang punggung keluarga dalam artian sebagai single parent(cerai mati atau cerai hidup), faktor kebutuhan relasi, bahkan ada yang semata-mata ingin mencari kesibukan yang menghilangkan kepenatan dalam rumah tangga. Namun demikian, kenyataan yang terjadi dilapangan, berdasarkan wawancara, faktor penyebab keikut sertaan perempuan dalam mencari nafkah mayoritas responden dari 20 perempuan yang saya teliti, menjawab bahwa faktor ekonomilah yang menjadi harapan dapat meningkatkan ekonomi keluarga. Berdasarkan kondisi lapangan didapati responden perempuan terbagi menjadi dua yaitu dengan kondisi single parent (tak bersuami), dan dalam kondisi bersuami. Dalam kondisi tak bersuami motivasi yang menjadi dasar keikut sertaan perempuan adalah dalam rangka mempertahankan hidup keluarganya, sedangkan kondisi bersuami peran perempuan yang memiliki motivasi dalam rangka menambah serta meningkatkan pendapatan keluarga.

Kondisi ini disebabkan karena single parent dengan berbagai kondisi (di cerai mati suami, dicerai hidup oleh suami dan karena pilihan menjadi single parent), permasalahan seputar perceraian atau meninggal, nafkah untuk memenuhi kebutuhan fisik anak 
dilakukan dengan cara bekerja diluar rumah (sektor publik). Kondisi demikian dijalankan seorang perempuan (single parent) karena keterpaksaan oleh keadaan untuk mempertahankan hidup serta pemenuhan kebutuhan keluarga. Selain itu adapula karena faktor kebutuhan relasi, semisal istri adalah buruh tembakau ditempat orang lain dan suami memiliki keahlian dibidang pembangunan atau renovasi, secara tidak langsung pembicaraan istri dengan teman-teman menjadi saran penyampai informasi terkait usaha yang dijalani suami.

\section{SIMPULAN}

Berdasarkan hasil penelitian dapat disimpulkan bahwa yang dilakukan wanita pengrajin Ampet di Desa Saba Kecamatan Janapria, ibu rumah tangga telah terbiasa mencari nafkah guna membantu suami dalam meningkatkan taraf ekonomi. Dari profesi ibu rumah tangga yang termasuk diantaranya pengerajin Ampet. Salah satu upaya perempuan yang berpartisipasi dalam pengrajin Ampet di Desa Saba Kecamatan Janapria menyediakan waktu luang untuk keluarganya. Banyak seorang perempuan yang menyisihkan waktu juga untuk keluarganya meskipun dia bekerja, dan tidak ada pengrajin yang menjawab tidak pernah sama sekali untuk meluangkan waktu bersama keluarganya, karena dalam pengrajin Ampet ini waktu untuk melakukannya itu tergantung dari pengrajin itu sendiri kapan dia mau melakukannya ataupun tidak.

Partisipasi kaum perempuan pengrajin Ampet dalam meningkatkan pendapatan keluarga di Desa Saba Kecamatan Janapria Kabupaten Lombok Tengah telah mampu membantu meningkatkan perekonomian keluarga, yaitu dapat membantu suami, disamping itu juga dapat membantu meningkatkan perekonomian rumah tangganya mencukupi kebutuhan keluarga dan membiayai sekolah anaknya, karena untuk itulah para ibu rumah tangga tersebut turut serta dalam mencari nafkah untuk keluarganya. Dalam pandangan Islam mengenai perempuan/ibu yang turut serta dalam berpartisipasi sebagai pengrajin Ampet dibolehkan, akan tetapi seorang istri harus mendapat izin dari suaminya terlebih dahulu serta tidak mengabaikan kewajiban-kewajibannya sebagai istri dan ibu dari anak-anaknya. Karena dalam islam antara laki-laki dan perempuan memiliki hak dalam melakukan aktivitas, baik dalam ekonomi, sosial dan politik.

\section{DAFTAR PUSTAKA}

Antonio, Muhammad Syafi'i. 2001. Bank Syari'ah: Dari Teori Ke Praktek. Jakarta: Gema Insani

Arikunto, Suharsimi. 2018. Prosedur Penelitian: Suatu Pendekatan Praktek. Jakarta:Rineka Cipta 
Azwar, Saifuddin. 2005. Metode Penelitian. Yogyakarta: Pustaka Pelajar.

Boediono. 2005. Teori Pertumbuhan Ekonomi. Yogyakarta: Bpfe.

Depag RI. 2005. Al-Qur'an Dan Terjemahnya. Jakarta: Al-Huda

Efebriani. 2011. Partisipasi Kaum Perempuan Dalam Meningkatkan Pendapatan Keluarga Menurut Perspektif Ekonomi Islam. Skripsi. Universitas Islam Negeri Riau

Fitriana, Rizqi Nikita. 2016. Pemberdayaan Perempuan Dalam Meningkatkan Kesejahteraan Keluarga Melalui Industry Kecil Di Pedesaan, Skripsi, Universitas Negeri Malang.

Gilarso, T. 2002. Pengantar Ilmu Ekonomika. Bandung: GanecaExcata

Husein Syahatah. 1998. Ekonomi Rumah Tangga Muslim, Terjemahan H. Dudung Rahmat Hidayat, Jakarta: GemaInsani

Imam Bukhari. 1987. Shoheh Al- Bukhari, Beirut: Dart Ibn al- Yamamah

Jaribah Bin Ahmad Al-Haritsi. 2006. Fikih Ekonomi Umar Bin Khatab,Terjemahan H. Asmuni Solihan Zamakhsyari, Jakarta: khalifah, Pustaka

Ma'arif, Syafi'i. 2003. Pembangunan Dalam Perspektif Gender. Malang: Umm Press

Mannan, Abdul. 1997. Teori Dan Praktek Ekonomi Islam. Yogyakarta: Dana Bhakti PrimaYasa

Moloeng. 2001. Lexy J. Metode Penelitian Kualitatif. Bandung: Remaja Rosdakarya
Moss, Julia Cleves. 1996. Gender Dan Pembangunan. Alih Bahasa: Hatian Silawati.Yogyakarta: Pustaka Pelajar

Munawarah Fikria. 2018. Studi Tingkat Partisipasi Perempuan Dalam Meningkatkan Perekonomian Keluarga Perspektif Ekonomi Islam. Skripsi. Universitas Islam NegeriAr-Raniry, Fakultas Ekonomi Dan Bisnis Islam, Banda Aceh

Zainuddin Ali. 2009. Hukum Ekonomi Islam, Jakarta: Sinar Grafika 